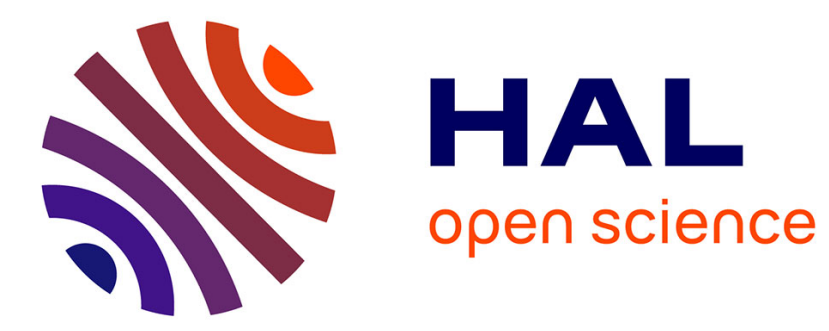

\title{
Peri-rural Populations in Search of Territory
}

Luc L. Bossuet

\section{To cite this version:}

Luc L. Bossuet. Peri-rural Populations in Search of Territory. Sociologia Ruralis, 2006, 46 (3), pp.214228. 10.1111/j.1467-9523.2006.00410.x . hal-02661063

\section{HAL Id: hal-02661063 https://hal.inrae.fr/hal-02661063}

Submitted on 30 May 2020

HAL is a multi-disciplinary open access archive for the deposit and dissemination of scientific research documents, whether they are published or not. The documents may come from teaching and research institutions in France or abroad, or from public or private research centers.
L'archive ouverte pluridisciplinaire HAL, est destinée au dépôt et à la diffusion de documents scientifiques de niveau recherche, publiés ou non, émanant des établissements d'enseignement et de recherche français ou étrangers, des laboratoires publics ou privés. 


\title{
Peri-rural Populations in Search of Territory
}

\author{
Luc Bossuet
}

\begin{abstract}
In the last 30 years increasing numbers of city dwellers have chosen to go and live in the countryside. This housing migration has led to a social redefinition of country living. It has reinforced the individualisation of lifestyles, thus contributing to a social and spatial redistribution of rural populations. Our article aims to analyse how rural residents of all origins relate to their environment and particularly to the different places they frequent. Concentrating on the material and symbolic investments made by families residing in a village located near Toulouse, we aimed to clarify the processes of territorialisation at play and thus to raise anew question of the relations between city and countryside.
\end{abstract}

$\mathrm{E}$ ver since the French population census of I975, housing migrations of city dwellers to the countryside have consistently increased. This movement can be explained by the fact that rural areas afford people the opportunity of acquiring their own property with a garden - a recreational place for adults and children alike - at a lower cost than in the city. Families maintain that in the countryside they have found an environment close to nature, free from pollution and urban stress, while retaining easy access to urban services, thanks to the improvement of transport infrastructure. These migrations have led to a significant social diversification of the urban exodus, and, consequently, to an important remodelling of the rural areas that have become home to former urban residents (Kayser I993). Yet this generalisation conceals notable differences between places and between people living in the same place. In view of such complexity, this study aims to understand and describe different types of territoriality by analysing the material, emotional and social relationships that the families develop in their daily living environment (Kaufmann 2004).

We chose a socio-anthropological approach, as it enabled us to analyse the diversity of practices and to account for individuals' relations with each other in face-to-face contacts or social distance from each other. This approach also enabled us to show that such practices are indicators of social relations between families and their neighbourhood, while taking into account the history of the different places and the successive waves of migration to them (Augé I992). Similarly, spatial mobilities are 
analysed as a response to the demands of contemporary life, but also as a means of fulfilling social aspirations, and above all, the desire for sociability (Chombart de Lauwe I970). Sociability, defined as the play form of socialisation (Simmel I98I), is at the basis of this research. We examine this sociability by concentrating on the geographical split of residential, professional and recreational space. We focused on the material and the symbolic construction of space as they are experienced, and on the social and spatial practices of residents (Bodeux 2002).

We suggest that the development of personal territories does not merely correspond to divisions based on socio-professional differences. Indeed, we believe that it rests on multiple social relations that are spatially differentiated and conditioned by individuals' histories and projects (Dubar 2002). In this context, the process of territorialisation corresponds to an organising dynamic, articulating space (used, experienced and imagined) and time (past, present and future), and objective and subjective representations. Thus, the territory corresponds to a set of landmarks that provides opportunities and fosters mobility, rather than immobility. This construction rests on the interdependencies between the residents (Granovetter I973), their antagonisms and alliances and the social and spatial strategies developed by each of them. Our approach was to try and assess to what extent length of residence influences individuals' investments in their private space and in their distant or close environment. We aimed to determine whether the status of 'old rooted resident' or that of 'migrant', attributed by the neighbourhood, influences modes of sociability that have been developed.

To study the differences in the socio-spatial and temporal investments of individuals and families resulting from the overlapping of rural and urban spaces in modern lifestyles, we have chosen to explore what we call a 'peri-rural' location - a term chosen by analogy with 'peri-urban areas'. This type of environment is characterised by low levels of housing and residents, with few collective and urban facilities, but providing quick access to the city. The analysis presented here is based on a survey of all adults living in a small village in south-west France, about 40 minutes from Toulouse (to the east), the main city in the region. We decided to conduct our survey at a commune level, as this best enabled us (in the French context) to identify historically the different waves of housing migrations and the involvement of the members of each family in the political and associative life of the local community. This article is structured in four sections. After briefly describing the socio-demographic and housing evolutions that have changed the life of the village since I93I, we studied the residential practices of these families. The latter were analysed by exploring, on the one hand, the families' different modes of occupation of their residence and neighbourhood relationships and, on the other hand, the residents' relations with the more distant places they frequent.

\section{Changes in a village in the Toulouse countryside}

In I93I, the village we studied was mostly populated with families of tenant farmers and five families of wealthy landowners, ${ }^{\mathrm{I}}$ among whom a medical practitioner, an engineer and an army officer. As everywhere else in France, the modernisation and mechanisation of agriculture, which began in the I950s, resulted in a rural exodus and 


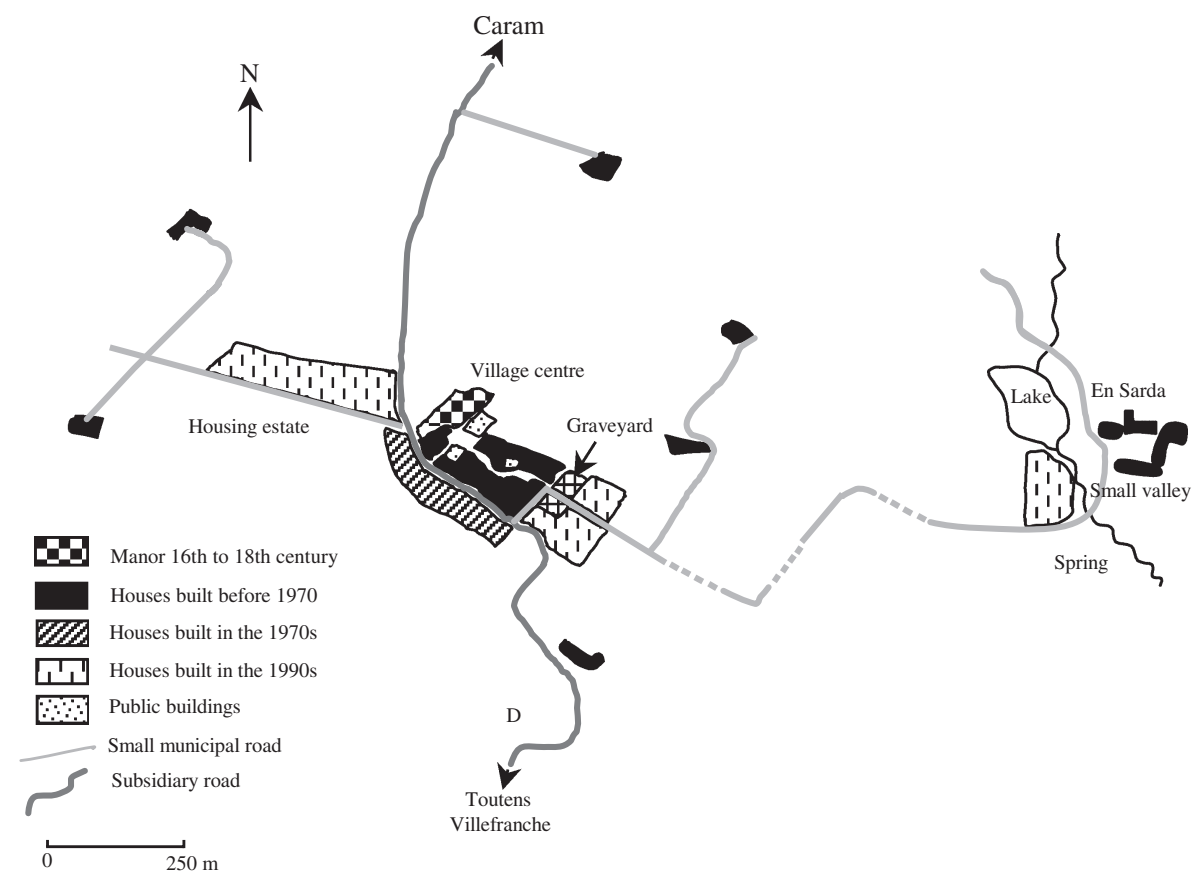

Figure 1: Location and age of buildings in 2001

in the direct exploitation of the land by landowners. The non-farming descendants of these landowners are today independent professionals or work in the senior civil service. They have kept their old family homes. Some of them live on their properties permanently, while others use it as a secondary residence. The village was home to iI 6 inhabitants in 1962 and to only 86 in 1986, of which one-third was retired. Between I962 and I986, the school closed down for lack of children and the grocer and café owner had to close their doors for lack of customers. Today, apart from the five remaining farms, only the car mechanic continues his activity. Collective life is inescapably declining. ${ }^{2}$ In I990, confronted with the gradual death of the village and pressure from the préfecture on the municipality to agree to joining the village to the district's main town close by, the municipal council decided to take action. Many Toulouse residents had already inquired about the availability of housing in the village. They were seeking 'rural authenticity', and even an 'assumed rural friendliness', but above all a 'house with character'3 at relatively low cost and located no more than an hour away from Toulouse, where they worked. Houses were available in the village centre and the surrounding countryside was dotted with unoccupied farmhouses. Several enclosed parcels of land and a municipality plot were also available for development (see Fig. I). In less than Io years, all these properties were sold and in I999 the village was home to I44 inhabitants, the same number of residents as in I93I. Nearly two-thirds (64\%) per cent of the population are former residents of Toulouse and have been living in the village for less than ro years. These housing migrations 
have resulted in a rejuvenation of the population. ${ }^{4}$ This new situation has several characteristics. Whereas in the past the population consisted mostly of farmers and their labourers, the latter now represent only 2 per cent of the working population. Audiovisual engineers, retail industry employees, industrial and building workers, artisans and merchants, teachers, researchers and independent professionals have replaced the farmers. ${ }^{5}$ But it is at level of housing that the differences between the families are most obvious.

At the end of the I970s, the residents of the old village centre, looking for more comfort, left their old pink brick houses and built individual houses in the southern part of the village, along a subsidiary road which, nowadays, runs through the village. In the I990s, the first migrants purchased the old houses of the old centre, and farmhouses dispersed through the countryside, or built villas outside the hamlet of En Sarda. From I995 onwards the western slope of the village expanded, thanks to the development of a municipal housing estate. Low-income families and young couples with no children settled there. In I997, a new wave of migrants bought plots located near the cemetery (just outside the village) or in the countryside and built houses that are for the most part larger than the houses in the housing estate.

Following these migrations, the village is now home to families of different geographic and social origins and with varying lengths of residence.

- The long-established residents can be divided into two groups. The old families of landowners occupy the old masters' houses and the larger farmhouses while the descendants of tenant farmers and one farmer occupy the southern part of the village centre, the old part of the En Sarda hamlet and a few old farmhouses.

- The migrants also live in different types of houses. The first wave and the latest wave of migrants, who are well off financially, live in the old village centre, old farmhouses and large new houses built in the countryside to the east of the village and to the west of En Sarda. The low-income migrant families live in new and smaller houses in the eastern and western parts of the village.

This socio-spatial distribution of houses in the village is a first obstacle to the development of social relations between residents. The inhabitants of the different parts of the village centre seldom socialise: 'We don't know the people who live in the villas. There's the road. Their children play there, ours play here.' The same situation is to be found in En Sarda. The hamlet is split by a stream that runs through a small valley; serving as a natural boundary that is seldom crossed: 'They aren't from here and we don't think like they do.' Added to this obstacle is the fact that, with the exception of the mechanic's garage, where people sometimes see each other, the only other place where people meet is the old municipal hall which is poorly equipped and is seldom used. One of the original villagers comments on the lack of social relations between the families, saying: 'They leave in the morning and come back at night. We never see them.'

The ways in which the families furnish their houses and gardens reflect different conceptions of rural living. They reveal the type of sociability the family develops. The practices of mobility are also revealing of the type of relationships individuals seek to develop or have developed with their neighbours. Residents can be divided 
into four family groups according to their length of residence, their social status, their cultural references and their involvement in local life. The first two groups consist of well-off, professional upper socio-economic categories of families. They consist of the old landowner families and the new well-off migrants. Though both groups have similar practices of mobility, they differ in terms of seniority of residence and their sociability locally. The descendants of tenant farmers and lowincome migrants represent the two other groups. They differ in terms of length of residence and in their sociability and mobility. Some of the low-income migrants have similar mobility and sociability practices to the descendants of tenant farmers, whereas other low-income migrants have similar mobility and sociability practices to those of well-off migrants. Thus mobility and local sociability differences divide low-income migrants into two categories.

\section{The house and the garden}

When living in the countryside means making a living from it: the descendants of tenant farmers

The descendants of tenant farmers are nowadays either retired or working farm labourers, employed by the local builders or in public works. Their homes have different architectural designs depending on where they are located in the village. In the countryside and in En Sarda, the houses are long, pink brick buildings surrounded with service buildings. In the village centre, the houses are all the same geometric-shaped boxes and are all painted white. The interior furnishings are similar. The kitchen is always the main living area in the home: 'We always gather in the kitchen and when friends come; this is where we sit. We've known each other for so long, there's no need to stand on ceremony.' Yet, this type of relaxed friendliness does not apply only to long-established relationships: some young couples, who have recently moved into the neighbourhood, and the person who conducted the survey were entertained in this room.

For these families, the house and garden have a productive function and are places of neighbourhood sociability. Homes situated outside the village centre feature an outdoor recreational area in front of the house. It consists of a tarred pavement along the plot, an arbour and a more or less spacious white gravelled area: 'On sunny days we come here with the children and the neighbours. In the summer we play pétanque.' Beyond this recreational area there is a large garden vegetable and orchard. In the village centre the gardens are divided into two parts. On the street side, small portions of garden are planted with flowers and shrubs, but no one spends any time on this side. Because they are on the street side, they do not provide the privacy that the owners require: 'We're in full view of everyone and there's also the noise of the traffic.' On the other side of the house, a small area used for entertaining friends and relations opens up into a large vegetable garden. This area requires regular maintenance to ensure that it provides most of the vegetables consumed by the family during the year: 'We only buy groceries. We produce the rest (vegetables, poultry, pork) ourselves.' 
The elderly couples who live in the village centre or in the countryside often produce more than they can consume. When they have no children to care for and when they have good relationships with their recently settled neighbours, they offer them vegetables in season, poultry and so on: 'When we come back from work we often find vegetables in the fridge. When we invite them for lunch or supper, they accept on the condition that we eat their chicken or duck.' In return families generally invite these elderly people for their children's birthdays, run errands for them or transport them when needed. A form of complementarity develops on the basis of a grandparent-parent-children type of relationship. The exchange of keys seals a pact of mutual assistance: 'They have the key to our house and we have theirs. In the winter, we regularly pop in to check that they're OK.'

\section{When living in the countryside means keeping one's distance: the landowner families}

Among the long-established landowners, one is now a jurist, one is an architect and one is a dentist, while others manage their own agricultural enterprises. They have developed elitist social relationships; 'In the area, we see five or six families who own two to three hectares of land.' The bourgeois residences and the castle they live in are surrounded with parks and large gardens. The high walls and hedges that surround their properties have a double function: they protect them from the wind and provide privacy. The interiors reflect a need for comfort and a marked taste for decoration with paintings, tapestries, pottery, antique copperware, and so on. Depending on the landlord's age, the social role he (or she) has given himself and the degree of formality he/she adopts with the interviewer in this survey, the latter is invited to sit either in the sitting room or in a study. As for neighbourhood relations:

We have little contact with the village people because our friends live elsewhere. For example, we often see Mr and Mrs M. from Ramonville (a small town outside Toulouse), and a few other landowners to whom we are related.

'We don't know the new residents; we know the old villagers. When we see them we greet them, but it goes no further than that.' In the summer, social interaction takes place in the garden - 'We invite our friends from Toulouse to come and enjoy the countryside' - and around the particular object which only this social group possesses: a swimming pool: 'We built our swimming pool for our grandchildren. In the summer they come and swim every day with or without their parents. Friends also enjoy it.'

\section{When living in the countryside means looking for autonomy: the well-off migrants}

The professional activities of these families are diverse. There are building contractors, merchants, teachers, researchers, lawyers, surveyors or audiovisual engineers and book illustrators. Although their houses are generally smaller than those of the group previously described, their interiors are relatively similar. A fireplace and antique furniture are often focal features. Their home is the environment where their diversified sociability is expressed. Some owners have regular social contact with their neighbours: 'We see C, the deputy mayor, once a week.' Others have less regular contact with acquaintances in their neighbourhood: 'Occasionally, Mr J visits us.' 
Others still, avoid relationships with the neighbourhood, preferring isolation: 'I left the city because I wanted peace and quiet, so I don't want to have to deal with the neighbours.'

Their gardens are also different. Some are planted with Mediterranean shrubs and trees - such as cypresses, pine and olive trees and lavender - while others contain fruit trees and ornamental shrubs. In these cases, the care given to the garden reveals the owner's taste for an ordered nature. Other gardens are kept natural: 'We left the city for the countryside, so we are not going to have the kind of neat garden they have in the city's parks' or, 'For me, living in the countryside means having space. So nature can do what she wants.' Regardless of these differences, as soon as summer comes, on weekends or holidays, houses and gardens are generally places for social interaction: 'In the winter we have few visitors, but as soon as it gets warm again all our friends from Toulouse come and visit us'; 'In the winter we stay indoors and we go out to Toulouse. In the summer, it's the other way round. We live out-of-doors and we entertain our friends there.' Depending on the family concerned, the residential space corresponds to different social constructions. For some, the home is a place of refuge surrounded with a fence that serves to define the impregnability of their territory. For others, it is a place of sociability, with no fencing of any kind, ${ }^{6}$ and is open to the neighbourhood and friends.

\section{When living in the countryside means staying away from the neighbours: the low-income migrants}

The low-income migrants are workers and employees, young teachers and young managers of the high-tech sector. ' The unusual concentration in the same housing area of families belonging to different professional and socio-economic categories can be explained by the fact that they have several things in common: they share the same reasons for choosing to settle in the village and for interacting with the local community in the way they do. For these low-income migrants, moving into the village was related to their wish to buy property: 'Here, the plots were affordable whereas in the Toulouse area, they were far too expensive for us.' Two other reasons mentioned are the disadvantages of living in a flat, the neighbours' noise, the lack of space and the desire to have more space for their children to play: 'With children, you can't live in a flat. We're on top of each other'; 'With a garden, the children are freer. They can make as much noise as they want, build shacks....' The families relate to their new house the way they related to their old home. The only difference lies in the fact that they now own their home and no longer suffer the disadvantages associated with high-density living.

For these families, the garden serves as a kind of buffer zone that protects them from the outside world, and to reinforce this protection they have fenced off their territory. Beyond this similarity, they use their private space differently. For some, the garden is an extension of the house, it is a place they must be able to use in the summer to live in and for entertaining their relations and friends. For this purpose, they have made terraces and planted hedges and flowers in the garden. For other families, the garden is a no man's land. Heaps of rubble still stand in the garden, no lawn has been sown and neither plants nor flowers have been planted. 
Outside their private space, the sociability of these families is generally minimal; especially in the case of those living in the villas: 'Occasionally the men play pétanque together'; 'In two years, we have had people for drinks three times and a barbecue twice. It's nice for the children.' These neighbourhood relationships must be seen for what they are. The couples, because of their strong need for individuation, aspire to a sociability that differs from that of their neighbours. Most of these families seldom have contact with the other residents of the village: 'We don't know the village people'; 'We live in our own houses, I know only the mayor and his two deputy mayors. This way nobody bothers us.'

\section{Neighbourhood and territorialisation}

\section{Preserving customs: a necessity for the descendants of tenant farmers}

The attachment of these families to village customs is related to the fact that the old community was founded on the mutual help on which farming was based: "We arrived here in I923. We, the Vs and the As have always helped each other. We didn't have the machines they have nowadays.' This aspect is reinforced by their strong participation in the various collective events and festivals organised in the village on a regular basis: 'We go with the Ds, the Ls and the As to the lotto and the village festival'; 'I help with the lunch for the festival':

For the children's Christmas party, my son goes around the village selling cakes. As for me, I help to organise the festival and I help prepare the meal for the old people's party.

The cohesion between these families and their solidarity in preparing the local festivities tends to reinforce the feeling of collective identity within their group: 'We mustn't lose the village customs. Traditions are important!' Because of this involvement, the other residents consider these families as the defenders of the village's old customs and traditions. As for these old farmer families, they find that the new residents and old landowners take very little part in the social events they organise: 'Those folks prefer to go somewhere else.' 'Even the mayor's son does not come to the festival.' They dismiss all those who stay away from the local events that they organise and blame them for their lack of relationships with the village residents: 'On election day, they all go to the polling station, but after that, there's nobody to be seen'; 'The newcomers don't take part in the village fair and then they demand things that don't exist, like a tennis competition!'

\section{Preserving their local power: a priority for the landowner families}

The landowners believe that the village's collective events no longer provide the opportunity to express the community's cohesion. For the oldest residents, these social events are replicas of times past. However, they think that these festivals help preserve the spirit of the community:

I always put in a brief appearance at the different events because it is important to show the people of the village that we are part of the same world. 
As the mayor of the village, I naturally have to be there when the festival committee organises the annual festivities. It is important to show the local folks and the migrants that the values of the village are still alive.

The younger generation feels less directly concerned: 'They are events for old people. Once I dressed up as Father Christmas.' This generation needs to feel directly concerned in order to take part: 'Since I became a municipal councillor, I have attended the mayor's lunch party. But that's it.' This position is revealing of the attention given by these families - all generations included - to the evolution of the village. They are all interested in the ongoing changes and are increasingly concerned that they might lose their local power:

The newcomers are still not integrated. The ones who arrived first and last are relatively autonomous because they are well off and ask for almost nothing. But those who live in the villas are more demanding; they want the city in the countryside. We might end up with a list of opposition candidates for the elections.

\section{Hopes and disappointments: the well-off migrants}

When they moved to the village, the well-off migrant families went to the municipal hall to register as voters: 'For us, this was important because it is our way of showing that we are part of the community.' Most of them inquired about the village collective life and some contacted the festival committee:

We used to be part of several associations where we lived before. When we arrived here, we naturally got in touch with the people who take care of things here.

Their initiative was welcome: 'When we visited C. he was very happy to see us because not many people are in the festival committee.' Based on their past experiences, these migrants proposed to diversify the festival's activities: 'As a lot of people don't take part in the festival's pétanque $e^{8}$ tournament, I offered to organise a tennis competition ... but I got no support.' They also suggested that the menu of the festival lunch be changed:

They serve a moujetade 9 at the festival lunch. It is the traditional dish of the region. But it is quite rich and on I5 July, it gets quite hot. We asked if we could have a more diversified menu with salads and a grill. Why not barbecue a whole lamb, since C. breeds sheep? But the people didn't want that.

Unable to make their mark, these migrants used these differences as a reason to withdraw:

At the festival meal, the old and the new residents were on opposite sides. What's more, they always spoke in patois, so we couldn't understand anything. After a while you get tired of it.

Even though social relations seemed friendly initially ('At the beginning people were simple, so contacts were easy'), they gradually became more distant. The well-off migrants withdrew from village life (Urbain 2002). ${ }^{\text {Io }}$ Their participation has declined: 'Life here reflects the village. Old customs can't be changed.... These days I only go to the receptions and I vote.' Finally, after three or four years, these migrants withdrew from local life; adopting the same attitude other migrants had had from the start: 'We 
came here to have peace and quiet. So we greet people, but that's all'; 'We vote and we help with counting the votes if we are asked.' The picture sometimes looks dull: 'They wanted new blood to pay taxes, but they don't want strangers.' With time, the differences seem to prevail: 'Here, all they're interested in is moujetade and rugby. We're not big fans, so they see us as strangers.' Neighbourhood exchanges end up being instances of minimal sociability.

\section{Between integration and lack of interest: the low-income migrants}

Depending on their past experiences, the low-income migrants developed different strategies that correspond to their idea of rural life. Those who were brought up in the countryside generally suffered from the anonymity of urban life during their stay in Toulouse:

We originally come from the Pyreneans; we couldn't stand the feeling of being isolated any more. So we decided to come and live in the countryside where people greet each other and chat, even though they don't know each other.

These families developed daily social relations with their neighbours regardless of how long they have lived in the village: 'I mostly socialise with the old people. They enjoy having visitors, and I like listening to their stories'; 'We chat with the neighbours and the wife and I take turns to take the kids to school.' Thanks to the network of social relations created, these families soon joined the festival committee without trying to change the way it functions, to modify its activities or to play a prestigious role in it: 'We vote and we are part of the festival committee. We give a hand and participate in all the local events.'

The families that had always lived in cities previously keep their distance. Some feel excluded from the village: 'We haven't lived here for very long. And as far as the village people are concerned, we are strangers whom they don't greet.' Other families show no interest in local life: 'They used to live without us, and we used to live without them. Nothing attracts me here so I don't see why I should make an effort.'

These distinctions do not stop most families in this category from asking the municipal council for the collective facilities they would like to have:

They asked for a pétanque court but they wanted it near their house. We have refurbished the existing court in the village centre so that it could also be used for the festival. They occasionally come and play.

\section{Mobility: a way of diversifying one's territory}

Whatever the pattern of sociability developed by each resident in the village, the families travel frequently, even though the distances travelled vary from one family to another. Two types of mobility exist, depending on the purpose, regularity and social relations they underlie. This mobility is primarily related to the necessities of life: work, school, shopping, recourse to the social and health services and so on. Secondly it relates to cultural or sports activities as well as to the residents' social relations with people outside the village. 
The descendants of tenant farmers privilege their relationships with neighbours

This and other neighbouring villages are the daily living environment of these families. There are several reasons for this. All the men in these families work in these villages: 'At the moment I'm building a house in Caraman (the district's main town $3 \mathrm{~km}$ away), but tomorrow I might work somewhere else in the area.' The women look after their homes, the garden and the children. To get to the primary and middle school in the neighbouring village of Caraman, the children use the school bus: 'The children go to school in Caraman. After middle school, we'll see.' Because of the geographical proximity of this rural centre, these families do their shopping and get the services they require there: 'We go to the market in Caraman every week. And at the same time we go to the doctor's if we need to'; 'When we need the services of an artisan, we go and see him on market day.' Market day is also an opportunity to exchange news with acquaintances who live in the area: 'During the week, we go to Caraman for supplies. This way we can see people we know, who live in the neighbouring villages.' The sports clubs, of which the families are members, are also concentrated in this rural centre: 'My daughter plays basketball and my son plays soccer in Caraman. I go to exercise classes there.' Moreover, these families all have a network of friends or relations within a radius of ıo $\mathrm{km}$ : 'We sometimes go to my sister's in Tarabel $(4 \mathrm{~km})$. And every year we go to Toutens $(2 \mathrm{~km})$ for the hunters' festival and the Lotto'; 'We see our cousins in Beauville $(3 \mathrm{~km})$. When the festival is here, they come with us. When there's a festival there, we go there.'

Apart from these destinations, the families mention two other places. The first is Revel. ${ }^{\text {II }}$ They occasionally travel here for 'out of the ordinary' purchases: 'When we have a lot of shopping to do, we go to Revel. We have our routines there and we know the shops.' By going to Revel they avoid going to Toulouse, whose bustle, noise and pollution they fear: 'In the last I5 years I've hardly been to Toulouse, because it's polluted. There's too much noise and I can't find my way around nowadays.' The other destination is the lake of Saint Ferreol $(28 \mathrm{~km})$ which has a beach and is equipped with recreational facilities: 'Once or twice a year, in the summer, we go to Saint Ferreol for a picnic and spend a day there.'

\section{The landowner families: a daily relationship with the city}

The landowner families travel to Toulouse every day for work and for school: 'My son and daughter-in-law work there. Their children go to school there.' Through this daily relation, these families can use the retailers and services available in the city: 'My wife works in Toulouse and she does the shopping for the week there.' What's more, Toulouse is for these families a place of cultural expression that breaks from the village environment of their home: 'We go to the theatre or to concerts in the city. We go to the movies in Villefranche ${ }^{\mathrm{I2}}$ because it is closer.' This relation is accentuated by the fact that the city is a place of social interaction with people they see regularly: 'We have a few friends in this areas, but most of our friends live in Toulouse, which is why we often go there.' This relation to the city does not stop these families from using the services available in their home environment for convenience - 'For common ailments, we go to the general practitioner in Caraman'; 'I go to Caraman twice to three 
times a week. My bank and suppliers are there' - or to preserve old links: 'We usually do our shopping in Caraman ... it's important to support local businesses.'

\section{The well-off families of migrants: long and short distance mobility}

These migrants combine long-distance mobility during the week and certain holidays and short-distance travelling the rest of the time: 'During the week, we go to Toulouse every day. On weekends and holidays we have decided we should stay here and enjoy the countryside.' As in the case of the landowner families, Toulouse is for these families a place where they work or where their children go to school: 'As we work in Toulouse, the children also go to school there. It is simpler this way'; 'The children have their music lessons there.' As was their habit in the past, these families continue to do their shopping in the city - 'We do our shopping there, just as we used to' - they use the health care services available there, 'We have a good doctor in Toulouse so we have no reason to change', and they go there for recreational purposes - 'I still go bowling once a week'; 'Some evenings, we stay in town to see movies showing at the Toulouse theatres, and then we go home'; 'The concerts of the Capitol orchestra are superb; we attend almost all of them.' Through these different purposes, these people maintain their relation with the city: 'In the winter, we regularly go to Toulouse for a night out with our friends.'

The choice of not going back to the city every weekend and their refusal to submit to the village social control lead these families to visit other centres close by. Using the retail shops and services available in proximity of their residence is a first step: 'On weekends we do our shopping in Caraman. If we want to go the cinema, we go to Villefranche'; 'One weekend we needed a doctor for one of the children. We called Camaran's doctor who was on duty and since then he has been our family doctor.' Their first contacts with neighbouring villages or towns are followed by the discovery of recreational opportunities corresponding to their aspirations: 'One day, on my way to the baker's I discovered there was a swimming pool in Caraman. Since then we have been going there regularly'; 'For the last two years we have been in the drama club in Caragoude $(3 \mathrm{~km})$; The children and we go and play tennis in Lanta $(5 \mathrm{~km})$, there's a nice atmosphere there.' These activities allow these families a break from their isolation in the village through social interactions with people who have the same practices and the same desire for sociability: 'We go to the swimming pool regularly and we meet the Ps there. Their children are the same age as ours. We visit each other fairly regularly.'

I've been a keen horse rider ever since I was young. Now I go to the riding club in Caraman. I met two young women there and have made friends with them.

The low-income families of migrants: the city or the countryside, two opposite choices

These families can be divided into two sub-groups. The first group of families continue to go to Toulouse regularly, as this is where they work and where their children go to school: 'When we arrived in the village, we asked ourselves where our children should go to school, so we gave them the choice. They both preferred to stay with their 
school friends in Toulouse.' Taking the children to school every day enables them to do their shopping where they always did before: 'Once a week, on the way back home, we do our shopping at the supermarket' - and to see the family doctor they had when they lived in town: 'For health care, we have kept our doctor in Toulouse. We trust him, so why should we change?' Thanks to this commuting, these people have preserved the relationships they had with the city before they moved to the countryside: 'For the time being I still play soccer in Balma where we used to live.' These families explain the maintenance of their relations with the city by the absence of relational opportunities and services in rural areas: 'Here, there is nothing. In Caraman, there isn't even an ATM [which is incorrect], so we never go, except on Sundays, to buy bread'. Intrinsically urban, these families had to leave the city in order to find more affordable property, but by privileging their mobility, they have developed no social relationships in their neighbourhood.

The second subgroup of families is characterised by a lesser degree of mobility. In most of these families one of the partners is not active on the labour market, which leads these families to choose Caraman's primary and middle schools for their children: 'It is very close and I don't work, so I can take him [her son] to school and fetch him.' This daily toing and froing gives the mothers opportunities to meet others and sometimes to help each other: 'Mrs L and I have agreed to take turns to take the children to school.' This solidarity sometimes has unexpected consequences: 'When taking the children to school, I met other mums who live in Caraman and other villages. Now we see each other regularly.' These daily visits to the rural centre have created new habits: 'When I take the children to school, I buy my bread there. Though once a week, my husband and I do our shopping in Toulouse, because it is cheaper.' Little by little, through meetings with other women, these mothers and their families have appropriated a new geographic space and have developed a type of sociability that suits them, breaking with the urban anonymity they disliked in the past: 'We gradually feel more and more at home. In Caraman and here, people are nice and easy to talk to. It's different from the city.'

\section{Conclusion}

The heterogeneous ways in which the families occupy their domestic surroundings and the different neighbourhood relations they developed show oppositions between the social groups and within the group of low-income migrants. The seniority of residence and the socio-economic and professional categories are not the only criteria that must be taken into account in order to classify the village's families. The social and political structure of the village must also be considered in order to characterise the alliances in place. The landowner families have a dominating role and intend to keep it. They defend the traditional forms of sociability, and in this respect are followed by the descendants of the tenant farmers and by those among the lowincome families with low mobility, who manage, in this way, to preserve their values and identity. These families support the municipality, and thus the demands from the well-off and low-income but mobile migrants can be discarded or ignored.

The practices of mobility of the different groups, and the corresponding integration of the families within specific networks of sociability, strongly contribute to the 
development of differentiated processes of territorialisation. The home community and neighbouring villages expand the living territory of the farmers' descendants and of the non-mobile, low-income families, as both these categories develop socialising interactions in their neighbouring environment. In this respect, these families show how interrelationships, a sense of belonging to a community and an integration promoting a sense of local identity can be developed.

The practices of mobility of the four groups - and, more specifically, their trips to Toulouse and Revel - enable us to understand the logic on which the families' processes of territorialisation is based. The families of farmers' descendants are the only ones who go to Revel, and they do so only exceptionally. This practice shows how deeply rooted these families are in their rural community. The other three groups go to the region's largest city on a regular basis but in different social and spatial ways.

The families of landowners and well-off migrants frequently visit the city centre of Toulouse. It gives them the opportunity to develop specific relational networks compatible with their common desire for anonymity and autonomy, and to distance themselves from their neighbourhood. Thus, far from being a uniting factor or a place where both groups meet, Toulouse actually contributes to their ignorance of each other.

The relationships of the mobile low-income migrants with the city confirm this socio-spatial division of urban people. These families go to Toulouse regularly. Having originated from these areas, they essentially visit the peripheral areas of the city, keep their old personal landmarks and maintain the relationships they have there. Housing migration has undoubtedly increased the number of their places of activity and functional commuting, but it has not increased their territorialisation capacity in the same proportion.

Thus, our survey shows that at the beginning of this twenty-first century, individuals relate to themselves and to others better when they have the ability to initiate and develop relational networks integrating and reaching beyond their local environment.

\section{Notes}

I In the I930s land estates were between I80 and 250 ha in size. They were divided into farms of about 30 ha each, that were exploited by the tenant farmers mentioned above.

2 It consists only of the old people's tea party, theannual mayor's party, the commemoration of Armistice Day on II November, the children's Christmas party and, above all, the village's festival.

3 Expression used by Soudière (I998).

4 In just Io years the average age of the village's population has fallen from 45 to 36 years.

5 Comprising 54, I6, I9 and 9 per cent of the active population respectively.

6 Not only do these properties have no fence but also their owners mow the area surrounding them and have planted flowers and shrubs on the banks along the dirt road leading to the house.

7 Audiovisual and IT industries, research.

8 Regional game of bowls.

9 Traditional dish of the region cooked for 3 to 4 hours, containing beans, bacon, duck or goose conserve (depending on the village). 
Io In his book about secondary residents, the author presents a similar situation.

II According to the latest population census, this second district centre, located $25 \mathrm{~km}$ away, is home to 7985 inhabitants. Its economy is dominated by agribusiness and the metal industry and for this reason Revel is an important trading centre for the eastern part of the département.

I2 Another district centre, I2 km away.

\section{References}

Augé, M. (1992) Non-lieux, introduction à une anthropologie de la surmodernité (Paris: Seuil) Bodeux, F. (2002) La mobilité résidentielle en Belgique: perspectives d'études sociologiques. Recherches Sociologiques 3 pp. 25-45

Chombart de Lauwe, P-H. (I970) Aspirations et transformations sociales (Paris: Anthropos)

Dubar, C. (2002) L'articulation des temporalités dans la construction des identités personnelles: question de recherche et problèmes d'interprétations. Temporalistes 44 pp. 4I-49

Granovetter, M. (1973) The strength of weak ties and no teas. American Journal of Sociology 78 pp. I360-I380

Kaufmann, V. (2004) La mobilité comme capital? Pp. 25-4I in B. Montulet and V. Kaufmann eds, Mobilités, fluidité ... liberté? (Brussels: University of Saint Louis)

Kayser, B. (I993) Des campagnes vivantes. Pp. 7-2I in Naissance de nouvelles campagnes (Marseilles: de l'Aube)

Simmel, G. (I98I) Sociologie et épistémologie (Paris: PUF)

Soudière, M. de la (I998) L'appel des lieux: une géographie sentimentale Pp. IO2-I37 in B. Montulet and V. Kaufmann eds, Mobilités, fluidité ... liberté? (Brussels: University of Saint Louis)

Urbain, J-D. (2002) Paradis verts, désirs de campagne et passions résidentielles (Paris: Payot)

Luc Bousset

Institut National de la Recherche Agronomique Science pour Action et le Développement Activités

Produits et Territoires Décison (INRA-SADAPT) 16 rue Claude Bernard 75231 Paris, Cedex o5 e-mail: Ibossuet@u-parisio.fr 